\title{
Performance evaluation of high capacity multi crop thresher on 'gram' crop
}

ABHISHEK PANDEY AND R. M. STEVENS

Received : 22.05.2015; Revised : 10.03.2016; Accepted : 22.03.2016

See end of the Paper for authors' affiliation

Correspondence to :

\section{ABHISHEK PANDEY}

Department of Farm Machinery and Power Engineering, Mahatma Gandhi Chitrakoot Gramodaya Vishwavidyalaya, Chitrakoot, SATNA (M.P.) INDIA Email : abhishekage@ gmail.com
- Abstract : The present study was undertaken on high capacity multicrop thresher for threshing gram crop at three different speeds of $550 \mathrm{rpm}, 600 \mathrm{rpm}$ and $650 \mathrm{rpm}$ at corresponding feed rate of $16 \mathrm{q} / \mathrm{h}, 18 \mathrm{q} / \mathrm{h}, 20 \mathrm{q} / \mathrm{h}$. Performance of the experimental thresher was evaluated with respect to threshing efficiency, cleaning efficiency, grain loss, grain breakage and the output capacity. In threshing gram, the maximum threshing efficiency was found to be 98.98 per cent at cylinder speed of $600 \mathrm{rpm}$ and feed rate $20 \mathrm{q} / \mathrm{h}$. Similarly cleaning efficiency was found 97.30 per cent at cylinder speed of $600 \mathrm{rpm}$ and feed rate $20 \mathrm{q} / \mathrm{h}$ while the maximum total grain loss was found 3.3 per cent at cylinder speed $550 \mathrm{rpm}$ and maximum feed rate $20 \mathrm{q} / \mathrm{h}$. The grain breakage was found 1.70 per cent at cylinder speed of $650 \mathrm{rpm}$ and feed rate $20 \mathrm{q} / \mathrm{h}$. The output capacity was found $9.62 \mathrm{q} / \mathrm{h}$ at cylinder speed of $600 \mathrm{rpm}$ and feed rate $20 \mathrm{q} / \mathrm{h}$. The net saving with multicrop thresher in threshing cost compared to traditional threshing method was found to be 31per cent for gram crop.

- KEY WORDS : Concave clearance, Feed rate, Tachometer, Threshing efficiency, Depreciation, Straw-grain ratio

- HOW TO CITE THIS PAPER : Pandey, Abhishek and Stevens, R.M. (2016). Performance evaluation of high capacity multi crop thresher on 'gram' crop. Internat. J. Agric. Engg., 9(1) : 94-101. 